\title{
Videokluby jako forma profesního vzdělávání učitelů: otevřenost komunikace z pohledu učitelü ${ }^{1}$
}

\author{
Eva Minařírová, Klára Uličná, Michaela Píšová, \\ Tomáš Janík, Miroslav Janík
}

\begin{abstract}
Abstrakt: Tato studie se zabývá videokluby jakožto intenzivni formou profesniho vzdèlávání učitelì. V teoretické části se zaméruje na profesní učicí se komunity a na využití videosekvencí $v$ rámci profesniho rozvoje učitelu. Poté je predstaveno naše pojeti videoklubü pro učitele anglického jazyka na základnich školách. Cílem prèdkládané studie bylo prozkoumat, jak účastnici videoklubi popisuji svou zkušenost s touto formou profesního rozvoje, predevšim své vnímání otevrenosti a kritičnosti ve videoklubech. Videoklubů se zúčastnilo 11 učitelu anglického jazyka, kteŕi pracovali ve trech skupinách. Zdrojem dat byly polostrukturované rozhovory s jednotlivými účastniky, prepisy videozáznamů posledniho setkáni videoklubui a e-mailové zpètné vazby účastnikì, které psali po každém ze setkáni. Data byla zpracována metodou tematické analýzy. Výsledky naznačuji, že ačkoli učitelé popisovali atmosféru videoklubů jako príjemnou a otevrenou, zjevně pocitovali nedostatek kritiky a prítomnost diplomacie a korektnosti. Jejich postoje ke kritice se ale lišily - některým chyběla, jiní ji naopak nevnímali jako nutnou součást videoklubù, jelikož každý $z$ učitelì má vlastni prístup a kritizovat je proto nežádouci. Tyto postoje otevíraji otázku, zda se $v$ některých skupinách nejednalo spíse o pseudokomunitu a vyhýbáni se konfliktu a jak tomuto nastaveni mohou tvuirci a facilitátoři podobných programů predejit.
\end{abstract}

Klíčová slova: videokluby, profesni rozvoj učitelì, profesni učici se komunita, video v učitelském vzdèlávání.

V oblasti výzkumu učitele a vzdělávání učitelů stojí v popředí zájmu již dlouhou dobu programy vzdělávání a profesního rozvoje, které podporují vytváření profesních učících se komunit a dlouhodobou spolupráci mezi učiteli. Ukazuje se, že tyto atributy souvisí s efektivitou programů profesního rozvoje a jsou považovány za jejich základní stavební kámen (Desimone, 2009, s. 184). Z výsledků výzkumu TALIS nicméně vyplývá, že v České republice je podle informací od učitelů

\footnotetext{
${ }^{1}$ Vznik této studie byl podpořen projektem GA ČR GA13-21961S Profesni vidèni a jeho rozvijeni prostrednictvím analýzy založené na videu ( $z$ pohledu učiteli̊ angličtiny jako cizího jazyka).
} 
učení se formou dlouhodobé spolupráce př́tomno $\mathrm{v}$ méně než polovině programů dalšího vzdělávání (Kašparová et al., 2015, s. 50). Začínají se ale objevovat snahy o posílení intenzivnějších forem profesního rozvoje, které podporují dlouhodobou spolupráci mezi skupinami učitelů a rozvoj profesního společenství (např. program Lesson study; Vondrová, 2016). Videokluby, které jsou předmětem našeho výzkumu, jsou př́ḱladem programu profesního rozvoje, který následuje trend podpory profesního společenství a dlouhodobé spolupráce a využívá skupinové analýzy videosekvencí z výuky účastníků (např. Sherin \& van Es, 2009). Jejich podstata spočívá $\mathrm{v}$ pravidelném setkávání malé skupiny učitelů, při kterém jsou diskutovány videosekvence z jejich výuky. Cílem takového programu může být naprríklad intervence do profesního vidění účastníků (Sherin \& van Es, 2009; Janík et al., 2016).

Účast na podobných programech ale mohou učitelé vnímat jako zatěžující. Jejich práce se vyznačuje izolovaností - prostor ve výuce je vyhrazen tradičně pouze jim a jejich žákům. Pro učitele může být nepř́ijemné, když do jejich prostoru vstoupí jiný učitel, bez ohledu na to, zda za účelem hodnocení nebo profesního rozvoje. Výzkum profesního rozvoje učitelů naznačuje, že je pro učitele př́nosné analyzovat videozáznamy vlastní praxe, a to jak individuálně, tak ve skupině (Gaudin \& Chaliès, 2015). To ale může pro účastníky představovat nepř́ijemnou situaci zapř́íčiněnou tím, že pořízení videonahrávky (tedy záznamu jejich práce) a její následná diskuse jsou zásahem do jejich interakčního prostoru ve třídě, který mnohdy považují za své „soukromí. Dalším zdrojem negativních emocí může být i diskuse nad videozáznamy výuky dalších účastníků programů profesního rozvoje, ve které je nutno postupovat opatrně $s$ ohledem na pocity jednotlivých účastníků i mocenské nastavení celé skupiny (srov. Lefstein \& Snell, 2011). Př́i zavádění a výzkumu podobných programů je tedy třeba věnovat pozornost nejen jejich př́nosům pro jednotlivé učitele a žáky, ale i vlastní zkušenosti učitelů $s$ touto formou práce a tomu, jak účast na podobných programech vnímají a prožívají.

V rámci projektu, jehož součástí je tato studie, jsme pracovali s praktikujícími učiteli anglického jazyka na základních školách, kteří se pravidelně setkávali ve videoklubech. Jelikož jsme si byli vědomi specifik a výše zmíněných úskalí této formy profesního rozvoje, předkládaná studie si klade za cíl zjistit, jak učitelé prožívali svou účast na videoklubech se zaměřením na to, jak subjektivně vnímali možnost hovořit otevřeně a kriticky $\mathrm{v}$ rámci setkání videoklubu.

V následujícím textu se nejprve budeme věnovat videoklubům jakožto formě profesního rozvoje a jejich teoretickým východiskům. Poté se zaměříme na naše pojetí videoklubů a jejich realizaci v rámci širšího výzkumného projektu. Dále budou představeny cíle této konkrétní studie a její metodologie a výsledky. $\mathrm{V}$ závěrečné diskusi nabídneme jejich interpretaci a propojení se současným stavem poznání této problematiky. 


\section{VIDEOKLUBY JAKO FORMA PROFESNÍHO ROZVOJE}

$\mathrm{V}$ této kapitole se nejprve zaměříme na teoretická východiska videoklubů v pojetí van Esové a Sherinové (2008). Videokluby jsou zástupcem a př́kladem formy profesního rozvoje učitelů, $v$ níž je využito video $\mathrm{v}$ rámci profesní učící se komunity. Právě na tyto dva aspekty videoklubů se soustředíme. $\mathrm{V}$ druhé části představíme náš př́stup, tzv. ProfiVi videokluby, které byly realizovány s učiteli anglického jazyka na základních školách.

\subsection{Teoretická východiska a cíle videoklubů}

Filozofie videoklubů navazuje na konstruktivistické, sociokonstruktivistické a situační teorie učení. Vychází se z toho, že vše nové je zpracováváno na základě předchozích znalostí a zkušeností, na základě předchozího porozumění. Profesní učení a profesní rozvoj je vnímán nejen jako proces individuální, ale zahrnující i rovinu profesní komunity a širšího kontextu (viz např. Shulman, \& Shulman, 2004). Sociální aspekt učení se je ve videoklubech zohledněn ve vytváření profesních učících se komunit - jednotlivých skupin videoklubů.

Videokluby zohledňují rovněž fakt, že učení je situované, a proto třída, kde učitel vyučuje, je silným kontextem pro jeho učení. Jednou z reprezentací praxe, kterými se profesní učící se komunity mohou zabývat a kolem kterých mohou situovat profesní učení a rozvoj, je video- záznam výuky. Ten je v učitelském vzdělávání v různých podobách využíván již od šedesátých let 20. století (viz Sherin, 2004 , s. 3). Video pomáhá ukotvovat učení ve třídách učitelů a jejich konkrétní kontext přenášet do programu profesního rozvoje.

Důležitým tématem při tvorbě programů využívajících video je typ a výběr videosekvencí - zda budou využity videozáznamy pouze částí výuky, resp. konkrétních výukových situací, nebo videozáznamy celých hodin, zda se bude jednat o video cizí nebo videa účastníků a kdo bude videomateriál vybírat. Největší otázkou jsou volby týkající se využití cizího videa nebo videa $\mathrm{z}$ výuky účastníků daného programu. Obě varianty s sebou nesou jak přínosy, tak úskalí. Cizí video může být účastníkům kontextově vzdálené, ale může usnadňovat kritickou diskusi nad jeho charakteristikami (Seidel et al., 2011). Naproti tomu videa jednotlivých účastníků jsou kontextově blízká, ale $\mathrm{v}$ rámci skupinové diskuse mohou vzbuzovat negativní emoce jak na straně učitele, jehož video je promítáno (ostych, neochota), tak na straně jeho kolegů, pro které tato situace může být nepř́ijemnou (Zhang, Lundeberg \& Koehler, 2015, s. 149). V některých př́padech, pokud je skupina nastavená na vyhýbání se konfliktu (viz níže), může využití vlastního videa bránit kritické reflexi výukové praxe. Jedná-li se ale o skupinu, která je skutečnou profesní učící se komunitou, může společná reflexe výukové praxe výrazně přispívat $\mathrm{k}$ individuálnímu i kolektivnímu profesnímu rozvoji. 
Profesní učící se komunita je $\mathrm{v}$ rámci profesního učení důležitým prvkem, jehož význam vzrostl $s$ nástupem tzv. kolegiálního či kooperativního profesionalismu v učitelství (přibližně od osmdesátých let 20. století; srov. Hargreaves, 2000, s. 162). Ačkoli termín profesní učící se komunita není jednoznačně vymezen, odkazuje obvykle ke skupině učitelů, kteří se po dostatečně dlouhou dobu setkávají a věnují se kolaborativním aktivitám vztaženým $\mathrm{k}$ problémům praxe. Pro profesní učící se komunitu by mělo být charakteristické především sdílení hodnotové orientace, vzájemná spolehlivost, péče a podpora (Westheimer, 1998), kolektivní zodpovědnost (Stoll et al., 2006), kolegiální a kolaborativní interakce či jasné diskurzní normy pro produktivní spolupráci (van Es, 2012). Důležitými aspekty jsou také vzájemná důvěra, respekt a podpora členů komunity, inkluzivní členství, otevřenost a partnerství. Je tedy zřejmé, že ne každá skupina učitelů, kteří pracují společně, tvoří učící se komunitu, která sdílí společný cíl. Grossmanová a kol. (2001) používají termín pseudokomunita (s. 995) pro skupinu, která se vyznačuje povrchní prátelskostí, ale vyhýbá se konfliktu, nevstupuje na tenký led zkoumání komplexních vztahů mezi výukovými praktikami jedinců a učením se žáků. Tickle (1994) $\mathrm{v}$ této souvislosti pracuje s pojmem klamný diskurs (deceptive discourse). Při zkoumání rozvoje profesního vidění $\mathrm{v}$ rámci videoklubů na podobný aspekt spolupráce v rámci profesní učící se komunity narazili i Lefstein a Snellová (2011). Jejich studie ukázala, že co lze ve videoklubech říci a co je ceněno, je ovlivněno mocenskými vztahy $\mathrm{v}$ rámci skupiny (s. 513). Tento trend může mít ale negativní vliv na dosažení cílů, které si programy profesního rozvoje kladou - tedy i na cíle, které jsme si kladli my v rámci ProfiVi videoklubi̊. Naše studie se proto zaměrila právě na aspekt otevřenosti a kritičnosti v rámci skupin videoklubů. Než se budeme věnovat podrobně cílům této studie, představíme naše pojetí videoklubů a popíšeme jejich realizaci.

\subsection{Průběh ProfiVi videoklubů}

V odborné literatuře je popsáno mnoho programů profesního vzdělávání kombinujících profesní komunity a využití videa včetně výzkumů, které je doprovázely (např. Problem Solving Cycle Koellner et al., 2007; STeLLA - Roth et al., 2011; videokluby - van Es \& Sherin, 2008; v českém prostředí nejnověji Lesson study - Vondrová, 2016). Výsledky těchto výzkumů ukazují, že efekty programů se netýkají pouze samotné práce $s$ videozáznamy (lepší schopnost analyzovat videozáznamy výuky), ale i učitelových znalostí obsahu (konkrétních oborových poznatků), jeho vlastní praxe (např. změna $\mathrm{v}$ př́stupu $\mathrm{k}$ otázkám ve výuce) a mají vliv i na studijní výsledky žáků (zachycené skrze výsledky vědomostních testů). Tyto výzkumné studie naznačují, že práce $s$ videozáznamy v rámci profesních učících se komunit $\mathrm{v}$ profesním vzdělávání učitelů slouží různým cílům, které pomáhá naplňovat (pro přehled viz Janík et al., 2016). Proto jsme se při př́ípravě programu profesního rozvoje pro učitele inspirovali ně- 
kterými prvky výše zmíněných programů, které se ukazují jako prospěšné pro profesní učení učitelů.

V našem pojetí jsou videokluby chápány jako pravidelná setkání skupiny praktikujících učitelů, kteří za účasti facilitátorů diskutují nad videosekvencemi z vlastní či cizí výuky (srov. van Es \& Sherin, 2008). Ačkoli byly naše videokluby inspirovány především programy z oblasti vzdělávání učitelů matematiky a př́rodních věd, měly čistě oborovědidaktický cíl spojený se specifiky výuky angličtiny jako cizího jazyka. Cílem našich videoklubů bylo rozvíjet profesní vidění ${ }^{2}$ účastníků, $v$ těsné návaznosti na jejich profesní vědění a jednání. Konkrétně jsme se zaměrili na rozvoj profesního vidění pro uvědomělý rozvoj komunikační kompetence žákủ. ${ }^{3} \mathrm{Na}$ teoretické úrovni videokluby vycházejí z př́stupu $\mathrm{k}$ učiteli jako reflektivnímu praktikovi (napřr. Schön, 1983) a konstruktivistických a situačních teorií učení a vyučování (viz výše). Skrze cílenou podporu reflexe a detailního zkoumání videosekvencí z výuky byl podporován rozvoj profesního vidění. Důraz na reflexi rozvoje komunikační kompetence žáků byl doplněn o rozvoj profesního vědění učitelů $\mathrm{v}$ této konkrétní oblasti, a to jak na úrovni diskuse teoretických poznatků (složky komunikační kompetence, komunikační učební úlohy ${ }^{4}$ ve výuce anglického jazyka), tak na úrovni jejich aplikace do praxe skrze navrhování (design) komunikační učební úlohy a její využití ve vlastní výuce, následované skupinovou diskusí nad videozáznamem realizované úlohy (žitá zkušenost a její reflexe). Blízké propojení výuky účastníků (nejen) skrze videosekvence jejich výuky a obsahu videoklubů reflektovalo nutnost situovanosti programů profesního vzdělávání.

ProfiVi videokluby byly navrženy jako série pěti setkání pro malé skupiny praktikujících učitelů. Každá skupina se skládala ze tří až čtyř učitelů a dvou facilitátorů - šlo o členy výzkumného týmu se zkušeností se vzděláváním učitelů. Před účastí na programu byli učitelé informováni o zaměření projektu (profesní vidění) i o formátu a rámcovém obsahu jednotlivých setkání.

Každé setkání ve videoklubech trvalo cca 90 minut a ve všech skupinách mělo podobný rámcový scénár. Před setkáním byly vybrány ${ }^{5}$ dvě videosekvence $\mathrm{z}$ výuky

\footnotetext{
${ }^{2}$ Profesní vidění lze považovat za jednu z dimenzí profesionality učitele. Tento koncept představuje schopnost učitelù identifikovat aspekty situace relevantní pro její pedagogický úspěch a přemýšlet o nich (např. Sherin, 2007; Minař́ková \& Janík, 2012).

${ }^{3}$ Komunikační kompetence je obecně přijímaným cílem cizojazyčné výuky (např. Společný evropský referenční rámec pro jazyky, 2002). V nejobecnějši rovině je definována jako schopnost výměny informací jazykově správně, efektivně a vhodně s ohledem na kontext.

${ }^{4}$ Učební úlohy zaměřené na obsah sdělení, tj. s akcentem na schopnost sdílet informace, plynulost projevu a vhodnost jazyka s ohledem na kontext promluvy. $\mathrm{Na}$ druhém konci kontinua jsou učební úlohy zaměrené na formu sdělení (tj. akcent na jazykovou správnost promluvy; podrobněji např. Littlewood, 1981, 2004).

${ }^{5}$ Učitelé měli možnost se podílet na výběru videosekvencí, této možnosti ale nevyužili. Videa proto byla vybírána facilitátory a zpravidla zaměřena na aktivity zahrnující viditelnou interakci v anglickém jazyce mezi žákem/žáky a učitelem, př́ipadně mezi žáky navzájem. Vybrané ukázky neměly reprezentovat př́íklady ani dobré, ani špatné praxe.
} 
anglického jazyka. Na setkání facilitátoři ( $v$ př́padě videa $\mathrm{z}$ výuky učitelů mimo danou skupinu) či samotní učitelé (v případě jejich vlastního videa) uvedli kontext dané videosekvence (stručná charakteristika tř́idy a prrípadně jednotlivých žáků, zaměření aktivity, co jí předcházelo a co následovalo apod.). Poté zhlédli účastníci celou videosekvenci a diskutovali o ní. Následně sledovali učitelé videosekvenci ještě jednou a byla jim ponechána možnost videosekvenci zastavit či se v ní vracet. $V$ průběhu sledování či poté mohli učitelé diskutovat a komentovat videosekvenci. Každá videosekvence trvala asi 3-4 minuty. Facilitátoři ve videoklubech hráli roli organizátorů a moderátorů diskuse, kteří př́padně otevírali nová témata formou otázek. Ačkoli byl scénář podobný pro všechny skupiny, facilitátoři neměli předem daná témata (kromě zaměření na rozvoj komunikační kompetence žáků). Proto byla díky otevřenosti diskusí konkrétní podoba setkání závislá na jednotlivých skupinách a na impulzech, které účastníci přinášeli.

Jednotlivá setkání videoklubu měla specifická zaměření (viz také obr. 1), která reflektovala nejen cíle programu, ale i nutnost postupně budovat skupinovou soudržnost. První setkání se soustředilo na představení programu a diskusi videosekvencí z výuky neznámých učitelů. Tento typ videosekvencí byl využit, aby se účastníci $\mathrm{v}$ relativně bezpečném prostředí seznámili s prací s videozáznamy a se svými kolegy, než budou muset komentovat svá videa navzájem. Při druhém setkání byly diskutovány videosekvence účastníků. $\mathrm{V}$ jeho průběhu začali facilitátoři klást otázky tý- kající se cílů učebních aktivit zobrazených ve videosekvenci a jejich vztahu $\mathrm{k}$ rozvoji komunikační kompetence, a tím zaměrovat pozornost účastníků. Třetí setkání zahrnovalo mimo jiné intervenci do profesních znalostí učitelů, a to v oblasti teorie týkající se komunikační kompetence a komunikačního potenciálu učebních úloh. Kromě sledování videosekvencí byli účastníci požádáni o společný design jedné komunikační učební úlohy. Tu po setkání adaptovali pro věk i jazykovou úroveň svých žáků a realizovali ve vlastní třídě. Tato výuka byla zaznamenána na video a její sestřih diskutován v rámci čtvrtého setkání. Na posledním setkání byly opět diskutovány jedna až dvě videosekvence $\mathrm{z}$ výuky účastníků a následně byl shrnut celý průběh videoklubů. Účastníkům byl poskytnut prostor pro narativní reflexi jejich zkušenosti s videokluby. $\mathrm{V}$ rámci shrnutí učitelé jak reflektovali a hodnotili svoji zkušenost $s$ touto formou profesního vzdělávání, tak navrhovali príipadné změny (podrobněji viz níže).

V rámci našeho projektu byly realizovány tři paralelní videokluby (školní, fakultní A, fakultní B). Setkání v jednotlivých videoklubech se konala pětkrát ve školním roce 2013/2014. Školního videoklubu se účastnily čtyřri učitelky, které byly zaměstnány $\mathrm{v}$ téže škole, a tento videoklub byl realizován př́mo na základní škole (odtud videoklub školní). Učitelky působily jak na prvním, tak na druhém stupni $Z S$ S. Fakultní videokluby $\mathrm{A}$ a $\mathrm{B}$ byly tvořeny učiteli z různých škol a jejich setkávání bylo realizováno v prostorech Pedagogické fakulty MU v Brně (odtud videokluby fakultní). Fakultního videoklubu A se účastnili tř́i 
učitelé a učitelky prvního i druhého stupně $Z \check{S}$, z toho jedna působila na alternativní škole. Fakultního videoklubu B se pak zúčastnili čtyři učitelé a učitelky základní školy na prvním i druhém stupni (blíže $\mathrm{k}$ účastníkům viz tab. 1).

Videokluby $\mathrm{v}$ našem pojetí (podobně jako v pojetí van Esové a Sherinové) nebyly navrženy čistě jako intervenční program, ale jejich design je úzce spojen $s$ doprovázejícím výzkumem. Jedna ze studií je předmětem tohoto textu. ${ }^{6}$

\section{Metodologie}

\subsection{Cíle studie}

V rámci širšího výzkumného a intervenčního projektu byly naším týmem navrženy a realizovány videokluby jako forma intenzivního programu profesního rozvoje (viz Janík et al., 2016). Kromě výzkumu týkajícího se profesního vidění a jeho rozvoje, který byl cílem videoklubů, jsme od učitelů získali i cennou zpětnou vazbu, která může být využitelná pro koncipování dalších programů profesního rozvoje. Cílem zde prezentované studie bylo prozkoumat, jak učitelé dle vlastních vyjádření prožívali svou účast na ProfiVi videoklubech se zaměřením na to, jak subjektivně vnímali možnost hovořit otevřeně a kriticky $\mathrm{v}$ rámci setkání videoklubu. Jak jsme zmínili výše, Lefstein a Snellová (2011) ve svém výzkumu totiž ukázali, že na vyjadrování $\mathrm{k}$ videosekvencím nemá vliv jen to, čeho si účastníci videoklubů všimli a jaké závěry z toho vyvozují, ale i jistá politická korektnost (aneb co je príijatelné, o čem se smí mluvit) nebo zdrženlivost ve vyjadřování zpětné vazby. Indicie, že tomu tak bylo i v našich videoklubech, se projevovaly jak v samotných setkáních, tak v průběžné zpětné vazbě od účastníků. Na závěr ProfiVi videoklubu byl $\mathrm{z}$ toho důvodu zařazen individuální rozhovor s učiteli, který tematizoval jejich vnímání těchto aspektů.

Jako indikátory otevřenosti a kritičnosti jsme zvolili následující: přijatelná a neprrijatelná témata (jak je vnímal sám účastník a jak je podle účastníka vnímali ostatní), přítomnost zpětné vazby a kritiky (od účastníka ostatním, od ostatních pro účastníka). $V$ datech se ale vynořovaly další aspekty, jako např. atmosféra ve skupině a důvody k (ne)kritičnosti. Podrobněji o nich pojednáme ve výsledkové části.

\section{2 Účastníci výzkumu}

Výzkumný projekt, jehož je tato studie součástí, pracoval v první fází s online videodotazníkem pro učitele anglického jazyka. Všichni učitelé z této fáze byli osloveni s nabídkou účasti ve videoklubech. $\mathrm{V}$ př́ípadě zájmu proběhla osobní schůzka, na které byly videokluby podrobně představeny spolu se všemi požadavky na účastníky. Všichni učitelé $(\mathrm{n}=11)$, kteří po oslovení projevili zájem, se nakonec videoklubů zúčastnili (dostupný výběr). Podrobný popis vzorku je $\mathrm{k}$ dispozici $\mathrm{v}$ tabulce 1 .

$\overline{{ }^{6} \text { Další studie se zaměřovaly např. na procesní a obsahovou stránku profesního vidění nebo na vztah profesního }}$ vidění, vědění a jednání - viz Janík et al. (2016). 
Tab. 1. Účastníci videoklubů

\begin{tabular}{|l|c|c|c|c|c|c|c|}
\hline Učitel & Pseudonym & Škola & Tŕída* & $\begin{array}{c}\text { Délka } \\
\text { praxe } \\
\text { v letech }\end{array}$ & Aprobace & Videoklub & $\begin{array}{c}\text { Zkušenosti } \\
\text { s videem } \\
\text { v rámci DVPP7 }\end{array}$ \\
\hline U1 & Ilona & A & 5. & 9 & $\begin{array}{c}\text { angličtina, výtvarná } \\
\text { výchova }\end{array}$ & fakultní B & ne \\
\hline U2 & Iveta & B & 9. & 9 & angličtina, chemie & fakultní B & ano \\
\hline U3 & Jolana & C & 3. & 4 & $\begin{array}{c}\text { učitelství } \\
\text { pro 1. stupeň }\end{array}$ & fakultní A & ano \\
\hline U4 & Libor & D & 7. & 11 & angličtina, čeština & fakultní B & ne \\
\hline U5 & Lada & E & 5. & 2 & $\begin{array}{c}\text { učitelství } \\
\text { pro 1. stupeň }\end{array}$ & školní & ne \\
\hline U7 & Linda & E & 2. & 2 & $\begin{array}{c}\text { učitelství } \\
\text { pro 1. stupeň }\end{array}$ & školní & ano \\
\hline U8 & Marek & G & 9. & 13 & angličtina, čeština & fakultní B & ne \\
\hline U9 & Olďriška & H & 5. & 17 & angličtina & fakultní A & ne \\
\hline U10 & Petra & E & 3. & 17 & $\begin{array}{c}\text { angličtina, speciální } \\
\text { pedagogika }\end{array}$ & školní & ano \\
\hline U11 & Vanda & E & 7. & 1 & angličtina & školní & ano \\
\hline
\end{tabular}

*Jednalo se o trídu, ve které probihalo porizováni videozáznamũ.

\subsection{Sběr dat}

Obrázek 1 představuje komplexní sběr dat, který probíhal v rámci širšího výzkumného projektu. V této studii byly využity tř̌i zdroje dat - e-mailové zpětné vazby účastníků po každém setkání, přepisy videozáznamů posledního setkání každé ze skupin a přepis výstupního rozhovoru s každým z účastníků. První dva zdroje dat byly sbírány za účelem získání obecné zpětné vazby pro realizátory videoklubů (průběžná a závěrečné). Výstupní rozho- vory měly naproti tomu za cíl prozkoumat zkušenost účastníků s otevřeností a kritičností v rámci jednotlivých skupin a doplnit tak data $\mathrm{z}$ videoklubů pro analýzu videoklubů samotných.

Prvním zdrojem byla průběžná zpětná vazba. $\mathrm{V}$ průběhu celého roku jsme po každém $\mathrm{z}$ videoklubů e-mailem žádali zúčastněné učitele o zaslání zpětné vazby. Učitelé měli za úkol zodpovědět tři otázky: Měl/a jste pocit, že si ze setkání něco odnášíte, že pro Vás bylo přínosné? Jak jste se na setkání cítil/a? Je něco, co byste si

${ }^{7}$ Další vzdělávání pedagogických pracovníků. 


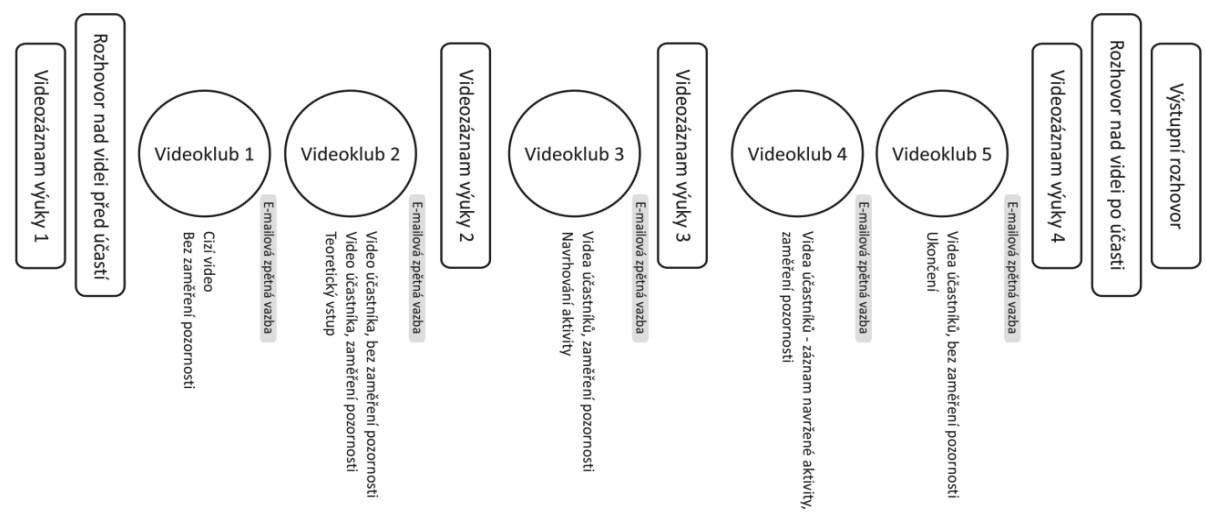

Obr. 1. Sběr dat v rámci projektu Profesní vidění....

představoval/a na setkání jinak nebo byste doporučoval/a změnit? Ačkoli tyto otázky přímo nekorespondují s výše uvedeným cílem, odpovědi učitelů obsahovaly vyjádření přímo se týkající jejich vnímání otevřenosti a kritičnosti v jejich videoklubu.

Dalším zdrojem dat byl přepis videozáznamu posledního setkání každé ze skupin. $\mathrm{V}$ něm byl na závěr shrnut celý program a účastníci byli vyzváni, aby komentovali celý program, shrnuli svou zkušenost a poskytli celkovou zpětnou vazbu (pozitiva, negativa a prípadné návrhy změn). Zadání bylo velmi obecné, konkrétní otázky byly pokládány pouze v návaznosti na vyjádření učitelů za účelem vyjasnění nebo doplnění informací. Ze setkání byl pořízen videozáznam, který byl následně transkribován pomocí programu Videograph (Rimmele, 2002) dle transkripčního systému, který byl užit v IVŠV videostudiich (Najvar et al., 2011).
Třetím zdrojem dat byl výstupní polostrukturovaný rozhovor s jednotlivými účastníky. Ten byl pořízen na úplný závěr programu a veden $s$ cílem získat jejich náhled na otevřenost a kritičnost $\mathrm{v}$ rámci videoklubů. Rozhovory se týkaly především témat, o kterých se ve videoklubech nemluvilo, a přítomnosti zpětné vazby, kritiky a známek diplomacie. Tyto otázky byly doplněny o témata zahrnující zapojení jednotlivých účastníků, impulsy, které vedly účastníky k zapojení se do diskuse, nebo návrhy na změny videoklubů. Rozhovory trvaly mezi 10 a 40 minutami a byly zaznamenány na diktafon a následně přepsány.

Důležitým zdrojem pro interpretaci získaných dat je i vlastní přímá zkušenost autorů textu, kteří se videoklubů zúčastnili jako facilitátoři, zachycená bud' ve vlastních poznámkách, nebo $\mathrm{v}$ audiozáznamech diskusí facilitátorů po ukončení 
jednotlivých setkání. Tato data nebyla analyzována rigorózně, ale sloužila jako opora pro interpretaci dat získaných od učitelů.

\subsection{Analýza dat}

Získaná data byla $v$ rámci otevřeného, převážně kvalitativního výzkumného přístupu zpracována metodou tzv. tematické analýzy (Braun \& Clarke, 2006). Data byla nejprve rozdělena do skupin podle toho, $\mathrm{k}$ jaké oblasti se účastníci vyjadřovali. Některé oblasti byly totožné s otázkami kladenými v rámci výstupního interview (deduktivní prrístup; např. př́tomnost kritiky a zpětné vazby obecně), jiné vyplynuly při pročítání dat (induktivní přístup; např. atmosféra). Tyto oblasti představovaly obecnější témata nebo aspekty účasti ve videoklubu. Jeden výrok mohl být zařazen do více oblastí. $\mathrm{V}$ rámci jednotlivých oblastí byly poté výroky sdružovány a byla hledána témata (induktivní prístup; např. vývoj atmosféry $\mathrm{v}$ čase). Identifikovaná témata byla následně promýšlena společně napříč jednotlivými oblastmi tak, aby bylo možné naplnit výše uvedený cíl - prozkoumání subjektivního vnímání otevřenosti a kritičnosti ve videoklubech. Dále se proto nevěnujeme všem tématům a oblastem, které se v datech vyskytly (pro další témata viz Janík et al., 2016), ale soustředíme se pouze na ty, které poskytují informace relevantni vzhledem $k$ subjektivnimu vnimáni otevrenosti a kritičnosti ve videoklubech.

Data byla částečně zpracována $s$ využitím softwaru MAXQDA. Analýza byla provedena jednou z realizátorek videoklubů, která se účastnila celého programu, byla facilitátorkou všech setkání dvou ze tř́i skupin videoklubů a byla $\mathrm{v}$ intenzivním kontaktu se všemi účastníky v průběhu celého programu (od oslovování účastníků po závěrečné rozloučení).

\section{VÝSLEDKY}

Tato analýza (i sběr dat) byla inspirována zjištěním Lefsteina a Snellové (2011), kteří ve svých videoklubech zaznamenali velký vliv „politické korektnosti“ - tedy toho, o čem se smí mluvit $\mathrm{v}$ současném nastavení společnosti obecně, i toho, kolik zpětné vazby lze ostatním členům skupiny poskytnout. Že se vliv politické korektnosti projevoval i v našich videoklubech, naznačovala i zkušenost facilitátorů. Jedna z facilitátorek při společné reflexi týmu hovořila o prvním setkání skupiny př́mo jako o „zjištování nastavení“ jednotlivých členů. Účastníci podle jejích slov otevírali různá témata a zjištovali, kdo se $\mathrm{k}$ nim při diskusi připojí, a zároveň si ověřovali míru kritičnosti, která je pro skupinu príijatelná.

Proto bylo překvapivé, že většinou vyjádření účastníků se prolínalo tvrzení, že atmosféra byla pŕíjemná, přátelská, kolegiální a nastavená $\mathrm{k}$ podpoře diskuse a že se tedy dalo mluvit o všem. $\mathrm{V}$ datech se ale dále často vyskytovaly indicie i př́má vyjádření, že tomu tak nebylo, alespoň ne zpočátku. Tři stěžejní témata naznačovala limity otevřenosti a kritičnosti ve skupinách - jednalo se o prítomnost diplomacie a korektnosti, nepŕítomnost kritiky a postupnou proměnu atmosféry $\mathrm{v}$ jednotlivých 
skupinách. Vyjádření respondentů často udávala i důvody pro tato omezení, která se většinou odvíjela od skupiny a jejích členů („záleží na skupině“). Shrnutí jednotlivých témat je zobrazeno ve schématu na obrázku 2. Stěžejní témata jsou zobrazena tučným písmem. Vztahy mezi jednotlivými tématy jsou naznačeny šipkami a spojovníky (šipky naznačují logiku argumentace účastníků, spojovníky naznačují pouze souvislost mezi výroky). Při analýze se objevily některé kontradikce ve vyjádření respondentů. Ty jsou v obrázku naznačeny tečkovanou čarou. Jednotlivá témata představíme blíže v dalším textu.
Někteří z respondentů (ze všech videoklubů) komentovali neprítomnost kritiky a kritické zpětné vazby. Zajímavá situace $\mathrm{v}$ tomto ohledu nastala napríḱlad ve fakultním videoklubu A. Jolana popisuje své vnímání nastavení skupiny na přijímání a poskytování kritické zpětné vazby. $\mathrm{Z}$ jejího vyjádření vyplývá, že dle jejího odhadu skupina zpětnou vazbu nechtěla. Opak se ukázal až na konci programu:

No já jsem právě do toho šla s tím, že třeba $v$ tomto jsem myslela, že mi to víc prinese, jako konstruktivni kritika. Já jsem méla zkušenost s mentoringem, že jsem absolvovala mentoring, ale to byl školený člověk, který

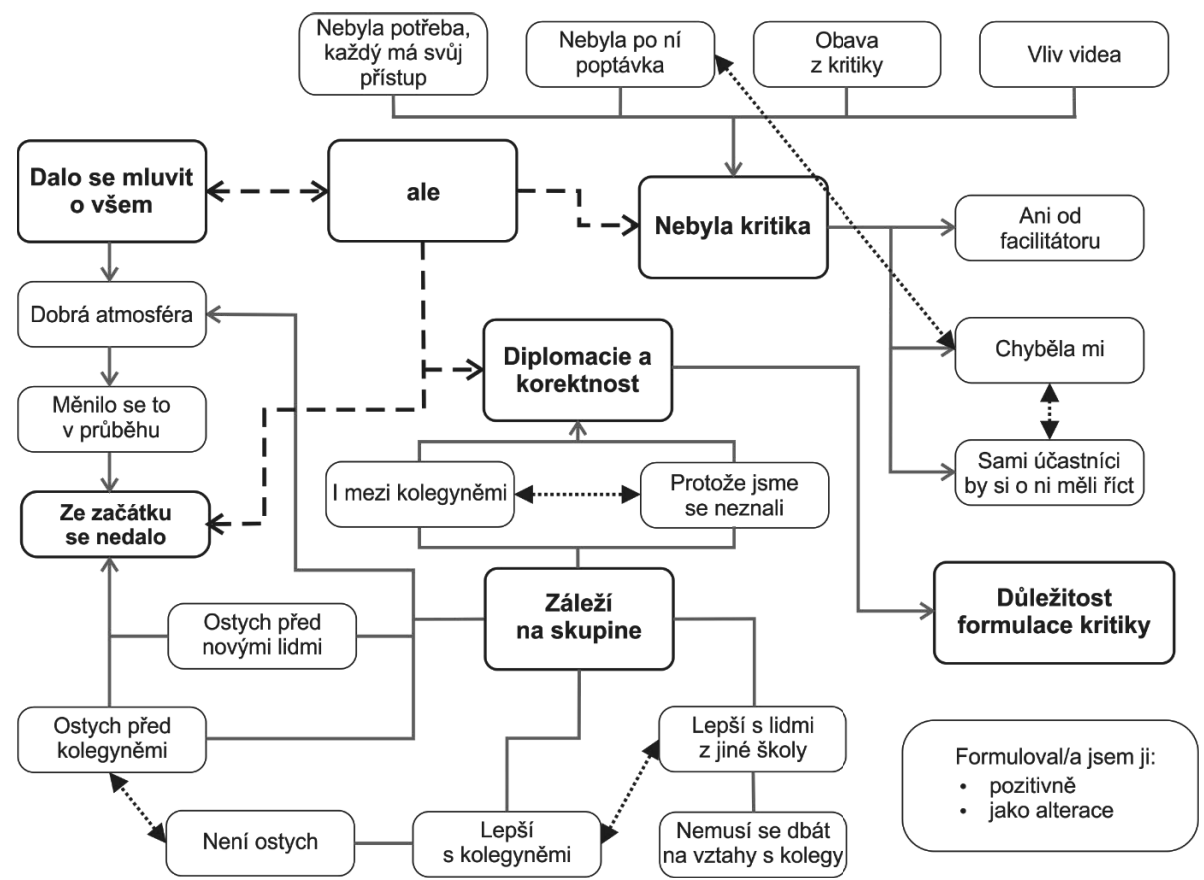

Obr. 2. Pohledy účastníků na otevřenost a kritičnost v ProfiVi videoklubech 
na to mél vzdèláni a dokázal to i tak jako uchopit citlivè, že jsem se třeba neurazila, když tam mél výtky ke spoustě věcí, protože samozrejmè člověk neni dokonalý, a tak. Ale tady... jak to ríct... jestli tady $k$ tomu ti ostatni pristoupili tak jako já nebo ne... Na konci jsem měla pocit, že ano, že ř́kali, že taky chtěli vic, aby to bylo trošku konstruktivni, nějaká ta kritika, aby se člověk posunul. Ale to jsem na začátku třeba taky nevèdèla, jestli to takble chtěji nebo ne. Protože když jsem se to nakonec dozvèdèla od kolegyné [Oldrǐsky; pozn. aut.], že to chtěla, tak to už vlastně byl konec. (Jolana, výstupní rozhovor)

Stojí za povšimnutí, že tato účastnice i její kolegyně ze stejné skupiny (Oldřišs$\mathrm{ka})$ vyjadřovaly již $\mathrm{v}$ průběhu programu ve svých zpětných vazbách poptávku po kritice (také od facilitátorů). Na rozdíl od Jolany, která nedostatek kritické zpětné vazby viděla jako důsledek nedostatečné poptávky, měla Oldřiška za to, že to bylo způsobeno výběrem videosekvencí:

Nevim, jestli to byl pocit, nebo jestli to byl zámèr, že vy jste vybirali ty sekvence, ke kterým někdy už se nedalo moc - třeba ta kritika tam nebyla tak rozvinutá, proto$\check{z}$ e v podstatě tam nebylo co. Třeba někdy ty sekvence - vzpominám si, nebo pamatuju, $\check{z} e v$ tèch hodinách ne vždycky v̌̌ecko vyšlo tak dobře, ale že na tom videoklubu to nevyplynulo, protože nebyla vidét celá ta hodina. Jestli to ríkám logicky správnè. Ale jinak nemám pocit, že bychom tam mèli problém o něcem mluvit, nebo aspoň já jsem neměla osobnè pocit, ̌̌e bych nemohla ríct - ehani kritiku, ani jakoby pochvalu nebo néco kolegưm nebo lidem, které jsme viděli. (Oldřriška, výstupní rozhovor)
Z porovnání výpovědí těchto dvou účastnic vyplývá, že ačkoli Oldřiška byla nastavena na poskytování konstruktivně kritické zpětné vazby a Jolana by ji ocenila, $\mathrm{k}$ její výměně podle vyjádření účastnic nedošlo $\mathrm{v}$ jimi očekávané míre, přestože Jolana hovořila o potřebě poptávky po zpětné vazbě. Je tedy otázkou, zda ona sama byla schopná poptávku dostatečně komunikovat, př́ípadně zda zbytek skupiny i přes poptávku od Jolany nevnímal poskytnutí kritické zpětné vazby jako vhodné. Další možnou interpretací je (dle zkušeností facilitátorů s pozorováním výuky Jolany), že videosekvence Jolany byly ostatními vnímány jako pŕíklady dobré praxe, ačkoli ona sama to tak nevnímala (když jsem to pak vidèla poněkolikáté ten [svioij] úryvek, tak jsem si řikala, že bych našla spoustu věcí. Takže si myslím, že i oni to museli vidèt; Jolana, výstupní rozhovor).

Účastníci $\mathrm{v}$ jiných skupinách uváděli jiné důvody pro nedostatek kritiky. Někteří neviděli kritiku jako vhodnou nebo žádoucí, nebot' uznávali, že každý má svůj př́stup. Smyslem videoklubů pro ně bylo rozebrat videosekvence a prípadně prodiskutovat alternativní řešení. Př́ikladem je vyjádření Libora (fakultní videoklub B):

Libor: Určitè se nekritizovalo, to tam bylo $v$ těch videich naprosto jasné, protože jsme všichni tam méli svưj prístup. Myslim si, že kritizovali hlavně majitelé těch videi, respektive ti učitelé. Vždycky řekli, proč nèco nevyšlo, to si pamatuju velice dobre. A nekritizovalo se. Ale to je otázka, jestli je to viobec potreba, protože se popsalo, co funguje a navrhlo se, jakým zpirsobem by se to mohlo dělat ještě jinak tréeba ve srovnáni s tèmi 
dalšimi videi. Toto tam určitě nebylo $v$ té skupinè.

V.: A chybèlo vám to?

Libor: Mnè to osobně, nevím, asi nechybělo. Protože minimálně treba já jsem si z tèch ostatnich videi vytábl to, jakým zpuisobem bych mohl treba príšstè postupovat, aniz bych to musel slyšet od kolegü. Jo, nechybèlo mnè to.

V.: Takže tak jak to bylo nastavené...

Libor: ...mi to vyhovovalo, každopádně ta setkáni byla opravdu prínosná. (Libor, výstupní rozhovor)

Další identifikovali projevy diplomacie a korektnosti. Někteř́ v tom, že se nemluvilo o všem (např. Marek, výstupní rozhovor), další vyzdvihovali důležitost podání zpětné vazby a formulace kritiky (pozitivní vyjádření, kritika skrze návrhy alterací). Důvodem korektnosti bylo podle účastníků to, že se s ostatními dobře neznali, což potvrzuje Milan:

Setkáni bylo proni, takže jsem se trochu "ostýchal", preci jen prvni kontakt s novými lidmi vždy zpi̊sobuje určitou nervozitu. (Milan, e-mailová zpětná vazba po prvním setkání)

Určitou míru zdrženlivosti v komunikaci ve videoklubech uváděly ale i kolegyně z jedné školy, které se pro společnou účast rozhodly dobrovolně a měly ve skupině již před začátkem programu blízké vztahy:

Co já sem si všimla. Já si myslím, že chápu, protože to vidim i z té své strany, že ze začátku jsme byly takové min - jenom takové opatrnějǔsi bych řekla. Že jsme nevédèly, co si müžeme dovolit nebo jak dalece se otevrít. Ale pak postupně mi prišlo, že to bylo úplně otevrené. Každý se zapojil tak, jak jako ho znám. Neřekla bych, že by někdone miñ - ale že tak, jak ty kolegyně znám, tak bych rekla, že se zapojovaly podle jejich možností. Neřekla bych, že by někdo neríkal nic, nebo že by se ostýchal néco řict, to vỉbec ne. (Petra, výstupní rozhovor)

To potvrzuje i výrok její kolegyně ze školy i ze školního videoklubu Lady:

Na minulém setkáni (kdy jsme vymýšlely aktivitu) jsem se citila opèt príjemnè. Sleduji určitý posun $v$ komunikaci s kolegyněmi, prédevšim ménè ostychu z toho, že bych mohla ríct třeba něco špatnè. Jsem ráda za takto vedenou diskusi. (Lada, e-mailová zpětná vazba po třetím setkání)

Důležitým tématem ve všech skupinách bylo postupné proměňování atmosféry, jak se skupina lépe poznávala. Jedna $\mathrm{z}$ účastnic (Jolana) např́íklad ve své vazbě k prvnímu setkání mluvila o nepř́ijemných pocitech (cizí lidé, nové prostředí), které se ale v druhé polovině setkání vytratily. Ve svých dalších zpětných vazbách označovala atmosféru za př́ijemnou (druhé a třetí setkání) a „již uvolněnější - více se známe“ (čtvrté setkání). Poslední setkání pak pro ni bylo nejpříjemnější a vyjádřila lítost, že videokluby končí. Podobná vyjádření se objevovala i u dalších účastníků. Ta potvrzovala postupnou proměnu nejen atmosféry, ale i možnosti vyjádřit se otevřeně a bez zábran (viz např. vyjádření Milana, Petry nebo Lady výše).

Účastníci ale netematizovali jen proměnu skupiny v čase, ale i její obecný vliv na videokluby jako celek (atmosféra, možnost vyjádřit svůj názor). V preferencích složení skupiny se nicméně projevovaly 
rozdíly. Kolegyně z jedné školy jednoznačně preferovaly videoklub takto nastavený. Důvodem bylo, že už se znají, nemusí se tak ostýchat (což je poněkud v rozporu $s$ jejich komentáři výše -zdrženlivost se ze začátku objevovala i $v$ jejich skupině) a je to prýnosné pro jejich další vztah. Naopak účastníci $\mathrm{z}$ různých škol př̀i přímé otázce, zda by se raději zúčastnili videoklubů $s$ kolegy, většinou preferovali nastavení videoklubu s učiteli z jiných škol. Dostatečným vyvážením nutnosti přenést se přes počáteční ostych pro ně byly variabilita pohledů a možnost setkávat se např́ic školami a porovnávat př́stupy nejen výukové, ale i týkající se školy a školního vzdělávání jako takových (podrobněji in Janík et al., 2016, s. 123). Zajímavé je, že jak účastníci fakultních videoklubů, tak účastníci školního videoklubu oceňovali i zjištění, že některé názory a pohledy sdílí s ostatními učiteli - že „, tom nejsou sami“, že existují podobně smýšlející učitelé (podrobněji in Janík et al., 2016, s. 124). Někteří z účastníků fakultních videoklubů také pozitivně vnímali oproštění se od opatrnosti a diplomatického vystupování, které by bylo nutné s ohledem na vztahy na pracovišti.

$\mathrm{Na}$ závěr musíme upozornit na rozpory, které byly přítomné ve vyjádřeních jednotlivých účastníků (např. ostych mezi kolegyněmi), ve vnímání komunikace naprríč jednou skupinou (poptávka po kritice; Jolana a Oldřiška) i v datech obecně (dalo se mluvit o všem, ale...). Tyto rozpory jsou vlastně dílčími výsledky naší studie. Ukazuje se, že ačkoli na první pohled probíhá komunikace ve videoklubech dle vyjádření účastníků bez potíží a lze hovo- řit o všem, není tomu tak od začátku programu. Atmosféra se mění v průběhu času a závisí na účastnících v dané skupině. Ani zde ale nedostáváme jednoznačnou odpověd', zda komunikace v očích účastníků probíhá snadněji (otevřeněji) ve videoklubech složených z kolegů či kolegyň z jedné školy nebo $z$ učitelů, kteří se vzájemně neznají. Naši účastníci naznačují výhody i nevýhody obojího. $U$ učitelů $\mathrm{z}$ různých škol je oproštění se od diplomacie nutné na pracovišti vykoupeno ostychem před cizími lidmi. Tento ostych dle kolegyň z jedné školy ve školním videoklubu odpadá, nicméně nutnost jisté „opatrnosti“ zůstává, jelikož se jedná o novou situaci.

Tyto rozpory $\mathrm{v}$ souvislosti $\mathrm{s}$ dalšími poznatky plynoucími z naší studie budeme diskutovat v následující kapitole.

\section{DiSKUSE A ZÁVĚRY}

Zpětná vazba od účastníků videoklubů, která byla $\mathrm{v}$ této studii analyzována, přinesla řadu zajímavých podnětů, které potvrzují poznatky z výzkumů. Důvodem pořádání videoklubů jako formy profesního rozvoje není jen profesní rozvoj učitele jako jednotlivce, ale i posílení kultury spolupráce mezi učiteli. Mnoho autorů upozorňuje, že výuka je izolovaná a izolující aktivita (srov. např. van Es et al., 2014a, s. 342) - učitel je ve výuce osamocen a oddělen od kolegů, kolegiální hospitace nejsou běžnou součástí života školy a jasně vymezený čas a prostor pro hlubokou diskusi nad konkrétními problémy praxe často chybí. V analýzách zpětných vazeb účastníků videoklubů se 
ale ukazuje, že právě překonání této izolovanosti a možnost sdílení jsou největším z prŕínosů tohoto programu (Janík et al., 2016, s. 124).

Jak ukazují předchozí výzkumy (viz výše), překonání izolace není jednoduché. Sdílet vlastní praxi může být pro učitele nepř́ijemné, stejně jako nutnost se (kriticky) vyjádřit k praxi kolegy (Zhang et al., 2015). I tyto aspekty videoklubů účastníci ve svých zpětných vazbách tematizovali. Ačkoli na první pohled se podle většiny účastníků zdála atmosféra příznivá a otevřená, učitelé pocitovali ostych (především zpočátku) a reflektovali postupné utváření komunity (dokladem může být vyjádření Jolany; viz výše). Obtíže při překonávání izolovanosti a př́i utváření profesní učící se komunity, která je otevřená kritickému diskursu, byly velkým tématem v komentárích učitelů. Nedostatek kritiky i jistá diplomacie a korektnost $\mathrm{v}$ diskusích byly účastníky často zmiňovány spolu $s$ identifikací jejich prríčin. Za zmínku stojí i to, že různí účastníci vnímali nedostatek kritiky různě. Někteří vyjadřovali zklamání, protože o ni měli zájem a do programu vstupovali s vidinou konstruktivní zpětné vazby na vlastní praxi (např. Jolana nebo Oldřiška). Prríčiny nedostatku byly vnímány různě - někteří účastníci necítili poptávku od ostatních (např. Jolana), jiní ke kritice neviděli důvod, nebot' každý učitel je jiný a má jiný př́ístup, což by nemělo být vnímáno negativně. Nabízí se ale otázka, nakolik je tento druhý př́stup prínosný pro profesní rozvoj účastníků. Je možné, že naznačuje právě jeden ze znaků pseudokomunity nebo klamného dis- kurzu - povrchní přátelskost a vyhýbání se konfliktu (srov. Grossman et al., 2001; Tickle, 1994). Zde do popředí vystupuje role facilitátorů jako těch, kteří pomáhají nastavit diskusní normy jak vlastním př́kladem, tak i explicitní tematizací cílů a forem diskusí v rámci videoklubů. Jak jsme zmínili výše, odklon diskusí z osobní roviny (tedy např. tematizování činností a vlastností učitele) a př́klon $\mathrm{k}$ analyzování procesů učení a myšlení žáků pomáhá debaty nad videosekvencemi zaměřit a odosobnit a otvírají tak možnost kritické analýzy, která ale necílí na jednotlivce a neohrožuje daného účastníka ani skupinovou dynamiku (srov. van Es et al., 2014b, s. 123).

Podpora sdílení, budování pozitivní atmosféry a podpora hlubších diskusí rezonovala návrhy na změny $\mathrm{v}$ organizaci videoklubů, které účastníci ve svých zpětných vazbách zmiňovali (podrobnosti viz Janík et al., 2016). Někteří navrhovali např́iklad prodloužení trvání programu, aby se mohla skupina lépe poznat, nebo konkrétnější zaměření jednotlivých setkání, aby se prohloubila diskuse.

Pohled na zpětnou vazbu účastníků a jejich osobní zkušenost $s$ videokluby umožňuje zamyslet se nad možnostmi využití videa $\mathrm{v}$ rámci profesních učících se komunit pro profesní rozvoj učitelů obecně i pro rozvoj jejich profesního vidění. Tato studie ukazuje, že realizace intenzivních forem programů profesního rozvoje má svoje úskalí. Při jejich tvorbě i implementaci je třeba počítat $s$ individualitou jednotlivých účastníků, a to nejen profesní, ale i osobní. Spolupráce 
v rámci profesních učících se komunit je do značné míry ovlivněna složením i nastavením jednotlivých skupin - a to zahrnuje i facilitátory, kteří jsou součástí skupiny a její dynamiky. Jejich roli je tedy třeba věnovat velkou pozornost, jelikož jsou to právě oni, kdo mohou podporovat vytvoření komunity a produktivního diskursu. Připravenost facilitátorů nejen po stránce odborné, ale i co se týče dovednosti práce se skupinou a facilitování diskuse je nezbytnou podmínkou. Nebezpečí klamného diskursu a neproduk- tivních diskusí je podle našich účastníků i existujících výzkumů značné a může ohrožovat naplnění cílů programů i jejich př́ínos pro profesní rozvoj účastníků. Věnování pozornosti tomuto fenoménu a skupinové dynamice obecně může napomoci ke zkvalitnění takových programů. Věříme, že naše studie je příspěvkem $\mathrm{k}$ diskusi na toto téma a bude impulsem nejen pro další výzkum $\mathrm{v}$ této oblasti, ale i při tvorbě a realizaci obdobných forem vzdělávání učitelů, resp. podpory jejich profesního rozvoje.

\section{Literatura}

Braun, V., \& Clarke, V. (2006). Using thematic analysis in psychology. Qualitative Research in Psychology, 3(2), 77-101. Dostupné z http://eprints.uwe.ac.uk/11735

Desimone, L. M. (2009). Improving impact studies of teachers' professional development: Toward better conceptualizations and measures. Educational researcher, 38(3), $181-199$.

Gaudin, C., \& Chaliès, S. (2015). Video viewing in teacher education and professional development: A literature review. Educational Research Review, 16, 41-67.

Grossman, P., Wineburg, S., \& Woolworth, S. (2001). Toward a theory of teacher community. Teachers College Record, 103, 942-1012.

Hargreaves, A. (2000). Four ages of professionalism and professional learning. Teachers and Teaching: History and Practice, 6(2), 151-182.

Janík, T., Minaříková, E., Píšová, M., Uličná, K., \& Janík, M. (2016). Profesni vidění a jeho rozvijeni prostrednictvím videoklubü. Brno: Munipress.

Kašparová, V., Holečková, A., Hučín, J., Janík, T., Najvar, P., Píšová, M., et al. (2015). Analytická zpráva z šetření TALIS 2013. Praha: Česká školní inspekce.

Koellner, K., Jacobs, J., Borko, H., Schneider, C., Pittman, M. E., Eiteljorg, E., et al. (2007). The Problem-Solving Cycle: A model to support the development of teachers' professional knowledge. Mathematical Thinking and Learning, 9(3), 273-303.

Lefstein, A., \& Snell, J. (2011). Professional vision and the politics of teacher learning. Teaching and Teacher Education, 27(3), 505-514.

Littlewood, W. (1981). Communicative language teaching. Cambridge: Cambridge University Press.

Littlewood, W. (2004). The task-based approach: Some questions and suggestions. ELT Journal, 58(4), 319-326. 
Minaříková, E., \& Janík, T. (2012). Profesní vidění učitelů: od hledání pojmu k možnostem jeho uchopení. Pedagogická orientace, 22(2), 181-204.

Najvar, P., Najvarová, V., Janík, T., \& Šebestová, S. (2011). Videostudie v edukačním výzkumu. Brno: Paido.

Rimmele, R. (2002). Videograph. Multimedia-Player zur Kodierung von Videos. Kiel: IPN.

Roth, J. K., Garnier, H. E., Chen, C., Lemmens, M., Schwille, K., \& Wickler, N. I. Z. (2011). Videobased lesson analysis: Effective science PD for teacher and student learning. Journal of Research in Science Teaching, 48(2), 117-148.

Seidel, T., Stürmer, K., Blomberg, G., Kobarg, M., \& Schwindt, K. (2011). Teacher learning from analysis of videotaped classroom situations: Does it make a difference whether teachers observe their own teaching or that of others? Teaching and Teacher Education, 27(2), 259-267.

Sherin, M. G. (2004). New perspectives on the role of video in teacher education. In J. Brophy (Ed.), Using video in teacher education (s. 1-27). Amsterdam: Elsevier.

Sherin, M. G. (2007). The development of teachers' professional vision in video clubs. In R. Goldman, R. Pea, B. Barron \& S. J. Derry (Eds.), Video research in the learning sciences (s. 383-395). London: Lawrence Erlbaum Associates Publishers.

Sherin, M. G., \& van Es, E. A. (2009). Effects of video club participation on teachers' professional vision. Journal of Teacher Education, 60(1), 20-37.

Shulman, L. S., \& Shulman, J. H. (2004). How and what teachers learn: A shifting perspective. Journal of Curriculum Studies, 36(2), 257-271.

Schön, D. A. (1983). The reflective practitioner. London: Basic Books.

Společný evropský referenčni rámec pro jazyky. Jak se učime jazykưm, jak je vyučujeme a jak v jazycich hodnotime. (2002). Olomouc: Univerzita Palackého v Olomouci.

Stoll, L., Bolam, R., McMahon, A., Wallace, M., \& Thomas, S. (2006). Professional learning communities: A review of the literature. Journal of Educational Change, 7, 221-258.

Tickle L. (1994). The induction of new teachers. London: Casell.

van Es, E. A. (2012). Examining the development of a teacher learning community: The case of a video club. Teaching and Teacher Education, 28(2), 182-192.

van Es, E. A., \& Sherin, M. G. (2008). Mathematics teachers' „learning to notice“ in the context of a video club. Teaching and Teacher Education, 24(2), 244-276.

van Es, E. A., Tunney, J., Golgsmith, L. T., \& Seago, N. (2014a). A framework for the facilitation of teachers' analysis of video. Journal of Teacher Education, 65(4), 340-356.

van Es, E. A., Tunney, J., Seago, N., \& Goldsmith, L. T. (2014b). Facilitation practices for supporting teacher learning with video. In B. Calandra \& P. J. Rich (Eds.), Digital video for teacher education: Research and practice (s. 109-126). Abingdon: Routledge.

Vondrová, N., Cachová, J., Coufalová, J., \& Krátká, M. (2016). „Lesson study“ v českých podmínkách: Jak učitelé vnímali svou účast a jaký vliv měla na jejich všímání si didakticko-matematických jevů. Pedagogika, 66(4), 427-442. 
Westheimer, J. (1998). Among schoolteachers: Community, autonomy, and ideology in teachers' work. New York: Teachers College Press.

Zhang, M., Lundeberg, M., \& Koehler, M. J. (2015). Affordances and challenges of different types of video for teachers' professional development. In B. Calandra \& P. J. Rich (Eds.), Digital video for teacher education: Research and practice (s. 147-163). Abingdon: Routledge.

Mgr. Eva Minař́ková, Ph.D.,

Masarykova univerzita, Pedagogická fakulta, Institut výzkumu školního vzdèláváni;

e-mail:minarikova@ped.muni.cz

Mgr. Klára Uličná, Ph.D.,

Masarykova univerzita, Pedagogická fakulta, Institut výzkumu školního vzdèláváni;

e-mail: klara.ulicna@pedf.cuni.cz,

doc. PhDr. Michaela Písová, M.A., Ph.D.,

e-mail:pisova.mich@gmail.com

doc. PhDr. Tomáš Janík, Ph.D.,

Masarykova univerzita, Pedagogická fakulta, Institut výzkumu školního vzděláváni;

e-mail: tjanik@ped.muni.cz

Mgr. Miroslav Janik, Ph.D.,

Masarykova univerzita, Pedagogická fakulta, Institut výzkumu školniho vzdèláváni;

e-mail:mjanik@ped.muni.cz

MINAŘíKOVÁ, E., ULIČNÁ, K., PÍŠOVÁ, M., JANÍK, T., JANÍK, M.

Videoclubs as a form of professional development: How open is the communication from the teachers' perspective

The study focuses on videoclubs as a form of intensive teacher education programme. The theoretical part discusses professional learning communities and the use of video in teacher education. Following this, our realization of videoclubs for teachers of English as a foreign language at basic schools is introduced. This study aims to investigate videoclub participants' experience with this form of teacher education, focussing especially on their views on how open and critical the communication in videoclubs was. 11 teachers of English as a foreign language took part in 
our study, working in three stable groups. The data included transcripts of semistructured interviews with individual participants, transcripts of the last videoclub meetings where teachers had a chance to provide facilitators with feedback, and e-mail feedback that the teachers sent in after each videoclub meeting. Thematic analysis was used to fulfil the research aims. The results suggest that even though the teachers described the atmosphere in videoclubs as pleasant and open, they felt the lack of criticism and the presence of diplomacy and correctness among colleagues. Their views on criticism differed, however. Some of them missed it whilst others did not perceive it as an important part of videoclubs as each teacher has their own approach and criticising is not desirable. That could, nevertheless, be a sign of pseudocommunity and of conflict avoidance rather than of critical colleagueship that is a desirable quality of professional learning communities. This opens a question of how designers and facilitators of similar teacher education programmes could promote open communication and critical colleagueship.

Keywords: videoclubs, teachers' professional development, professional learning community, video in teacher education. 